Elsevier

JVM 00461

\title{
SANDWICH NUCLEIC ACID HYBRIDIZATION: A METHOD WITH A UNIVERSALLY USABLE LABELED PROBE FOR VARIOUS SPECIFIC TESTS
}

\author{
H. WOLF, U. LESER, M. HAUS, S.Y. GU and R. PATHMANATHAN \\ Max-von-Pettenkofer Institute, Pettenkoferstrasse 9a, 8000 Munich 2, F.R.G.
}

(Accepted 11 October 1985)

\begin{abstract}
Nucleic acid hybridization is widely used for scientific applications but essentially restricted to specialized laboratories. The use of recombinant $\mathrm{m} 13$ phages as hybridization probes (Hu and Messing (1980) Gene 17 , 271; Messing (1983) Methods Enzymol, 101, 20) offers a considerable advantage over the commonly used recombinant plasmids as the preparation of the DN $\wedge$ probe is very simple and it can easily be labeled directly, e.g. with isotopes with long half-life like ${ }^{125}$ I (Commerford (1971) Biochemistry 10, 11 (1983); Gu et al. (1983) Cancer (China) 2, 129; Han and Harding (1983) Nucleic Acids Res. 11, 14) and used for hybridization. However, as the application of nucleic acid hybridization for diagnostic and epidemiological purposes becomes almost unavoidable, the logistic problems of keeping numerous individually labeled hybridization probes increase considerably and may reach prohibitory levels in less well-equipped laboratories.

In a new sandwich technique, the first step involves hybridization with an unlabeled recombinant $\mathrm{m} 13$ DNA carrying an insert of the desired specificity. In a second step a universally usable labeled probe directed against the $\mathrm{ml} 3$ part of the recombinant phage DNA is applied. This reduces considerably the problems of preparing and keeping multiple labeled probes in stock.
\end{abstract}

nucleic acid hybridization sandwich formation diagnostic hybridization cytomegalovirus m13 phage

\section{INTRODUCTION}

The most important requirement for nucleic acid hybridization concerns the preparation of hybridization probes. In vivo labeling of nucleic acids by metabolic pathways has been used to obtain probes. The main difficulties are the usually limiting low-specific activity (Frenkel et al., 1976), the difficulty of obtaining enough labeled material, and the problem of contaminating or cross-reacting sequences. These sequences may be due to incomplete purification of the desired gene, for example from cell lysates, or can be due to sequences within the genome used as a probe. DNA of the various herpes viruses is a typical example as several areas of the viral genomes cross-hybridize with DNA from uninfected human cells (Peden et al., 1982). Recombinant DNA techniques overcome the problems of limited availability of probes and allow the use of selected fractions of the viral genome without cross-reacting areas. Recently, the single-strand- 
ed DNA phage m13 has been used as a cloning vehicle for probes (Messing, 1983). This approach is very helpful as $\mathrm{m} 13$ sequences rarely occur in natural specimens and need not be removed prior to hybridization with the clinical specimen. The singlestranded recombinant phage DNA can be purified in large amounts without ultracentrifugation or other expensive equipment. Single-stranded DNA can be labeled by primer-directed synthesis of a second strand which spans all or part of the $\mathrm{m} 13$ sequences ( $\mathrm{Hu}$ and Messing, 1980) or by chemical reactions (Gu et al., 1983; Han and Harding, 1983; Prensky, 1976). Although the method itself does not require costly equipment and can be used on a larger scale, many laboratories need to have in stock a large number of labeled probes with differing specificities. This paper provides an alternative protocol where only one universally labeled probe is needed. In combination with simple devices for the collection of clinical specimens (Richter et al., 1983) and protocols for rapid sample preparation (e.g. Bresser et al., 1983) nucleic acid hybridization should become acceptable for routine laboratory use and for applications in diagnostic laboratories where very high sensitivity is frequently not important.

\section{METHODS}

\section{Preparation of probe-DNA}

Single-stranded m 13 DNA (Hu and Messing, 1980) and double-stranded $\mathrm{m} 13 \mathrm{mp} 8$ DNA (replicative form, RF) (Maniatis et al., 1982) were prepared by standard procedures described in detail in the references quoted. $\mathrm{m} 13 \mathrm{mp} 8$ was used as the source for the replicative form and as vector for (a) a fragment of a SauIIIa digest of the Bam H1W fragment of EBV-DNA, named EBWS9, which represents about $3 \%$ of the total viral sequences, and (b) a $3000 \mathrm{bp}$ fragment of a Bam H1/SalI digest of Eco RI J-fragment of HCMV AD169 DNA.

\section{Iodination of single-stranded DNA}

$10 \mu \mathrm{g}$ of $\mathrm{m} 13 \mathrm{ssDNA}$ with the specific insert were lyophilized. $1 \mu \mathrm{l}$ water, $2 \mu \mathrm{l} 0.25 \mathrm{M}$ Na-acetate buffer, pH 4.65, $15 \mu \mathrm{l}^{125} \mathrm{I}$ (Amersham, IMS30, $100 \mathrm{mCi} / \mathrm{ml}$ ), $2 \mu$ l thallium III chloride ( $100 \mathrm{mM}$ in buffer) were added. The tightly closed tubes were incubated for $30 \mathrm{~min}$ at $60^{\circ} \mathrm{C}$, chilled on ice and the reaction was stopped by the addition of $150 \mu \mathrm{l}$ stop mix (100 mM Tris, pH 8, $10 \mathrm{mM}$ EDTA, $10 \mathrm{mM} \mathrm{Na} \mathrm{SO}_{3}, 100 \mu \mathrm{g} / \mathrm{ml}$ poly A). The probe was purified on a $5 \mathrm{ml}$ Sephadex G50 column with $10 \mathrm{mM}$ Tris/pH $8.0,1 \mathrm{mM}$ EDTA. Fractions of approximately $300 \mu \mathrm{l}$ were collected and the first peak of radioactivity was pooled, heated $10 \mathrm{~min}$ at $60^{\circ} \mathrm{C}$, extracted with phenol/TE and ether and stored in a lead container in the dark at $-20^{\circ} \mathrm{C}$.

\section{Nick-translation of m13 DNA (RF)}

m $13 \mathrm{mp} 8$ RF DNA was labeled with [ $\left.{ }^{32} \mathrm{P}\right] \mathrm{dCTP}$ using the nick translation kit of Amersham. $250 \mu \mathrm{Ci}\left[{ }^{32} \mathrm{P}\right] \mathrm{dCTP}$ (Amersham $\left.10 \mathrm{mCi} / \mathrm{ml}\right), 20 \mu$ nucleotide buffer ( 100 $\mu \mathrm{M}$ dATP, $100 \mu \mathrm{M}$ dGTP, $100 \mu \mathrm{M}$ dTTP in Tris, $\mathrm{pH} 7.8$ ), $1 \mu \mathrm{g} \mathrm{m} 13 \mathrm{mp} 8 \mathrm{DNA}$ (RF), 10 
$\mu \mathrm{l}$ enzyme (DNase and polymerase) in a total volume of $100 \mu \mathrm{l}$ were incubated for $2 \mathrm{~h}$ at $14^{\circ} \mathrm{C}$. The DNA was separated over a Biogel A $1.5 \mathrm{~m}$ column and eluted with $10 \mathrm{mM}$ Tris- $\mathrm{HCl} 7.4,5 \mathrm{mM}$ EDTA, $100 \mathrm{mM} \mathrm{NaCl}$.

\section{Preparation of nitrocellulose membranes with test DNA}

EBV-Bam H1W fragment cloned in pBR322 was spotted on nitrocellulose paper (Schleicher and Schuell, BA85, $0.45 \mu \mathrm{m}$ ) as sample DNA in descending amounts. The moles spotted were as follows: $0.7 \times 10^{-15}, 0.7 \times 10^{-16}, 2 \times 10^{-17}, 0.7 \times 10^{-17}, 2 \times 10^{-18}$, $0.7 \times 10^{-18}, 2 \times 10^{-19}, 0.7 \times 10^{-19}$. Several series of these titrated indicator sequences were prepared and used for the experiments described.

\section{Preparation of urine for detection of human cytomegalovirus (CMV)}

$5 \mathrm{ml}$ of urine were centrifuged at $3,000 \times g$ and the low speed pellet redissolved in water. The supernatant was centrifuged at $50,000 \times g$ to obtain a high speed pellet. Both pellets were treated according to Bresser et al. (1983) and spotted on nitrocellulose paper. The washing procedures were similar to Bresser et al. (1983), except that the air dried filter was baked for $2 \mathrm{~h}$ at $80^{\circ} \mathrm{C}$.

\section{Sandwich hybridization}

Prehybridization Nitrocellulose filters containing the DNA fragments or the prepared clinical samples were prehybridized for $3 \mathrm{~h}$ at $68^{\circ} \mathrm{C}$ in $0.2 \mathrm{ml} / \mathrm{cm}^{2}$ prehybridization mix: $6 \times$ SSC, $0.5 \%$ SDS, $5 \times$ Denhard solution $(1 \times: 0.02 \%$ Ficoll, $0.02 \%$ polyvinylpyrrolidone, $0.02 \% \mathrm{BSA}$ ), $100 \mu \mathrm{g} / \mathrm{ml}$ calf thymus DNA (preheated at $100^{\circ} \mathrm{C}$ for $10 \mathrm{~min}$ and chilled to $4^{\circ} \mathrm{C}$ ).

Hybridization (sequence specific step) The prehybridization mix was removed from the bag to leave $50 \mu \mathrm{l} / \mathrm{cm}^{2}, 1 \mu \mathrm{g}$ single-stranded $\mathrm{ml} 3 \mathrm{DNA}$ carrying an insert of the desired gene and $10 \mathrm{mM}$ EDTA were added to the remaining buffer mix. The resealed bag was incubated for $16 \mathrm{~h}$ at $68^{\circ} \mathrm{C}$. The filter was washed in $2 \times \mathrm{SSC}, 0.5 \%$ SDS for 5 min at room temperature and then in $0.1 \times \mathrm{SSC}, 0.5 \%$ SDS $2 \times 20$ min at $68^{\circ} \mathrm{C}$.

Posthybridization (common step for different sequences) Posthybridization was carried out with denatured ${ }^{32} \mathrm{P}$ nick-translated DNA probe prepared from $\mathrm{m} 13 \mathrm{mp} 8$ double-stranded replicative form of bacteriophages without an insert. The specific activity of the nick-translated probe was $10^{8} \mathrm{cpm} / \mu \mathrm{g}$. The filter was incubated with hybridization solution as in step $2.10^{7} \mathrm{cpm}$ of the ${ }^{32} \mathrm{P}$ nick-translated probe (preheated at $100^{\circ} \mathrm{C}$ for $5 \mathrm{~min}$, cooled to $4^{\circ} \mathrm{C}$ ) were added and the bag was incubated for $16 \mathrm{~h}$ at $63^{\circ} \mathrm{C}$.

The washing procedure was similar to the above, but the temperature was $63^{\circ} \mathrm{C}$. After washing, the paper was dried and cxposed bclow $-60^{\circ} \mathrm{C}$ with Kodak X-Omat $\mathrm{S}$ film and lightning plus amplifying screen. 


\section{RESULTS}

The only way to avoid labeling each specific hybridization probe is to use a sequence of the DNA probe itself as a specific and recognizable sequence. This requirement can be fulfilled if the hybridization probe has at least a set of two unrelated sequences, one carrying the sequence with the desired specificity, e.g. to viral sequences, the other having a sequence which is not represented in the sample materials and which can be introduced in all probes. We used, besides Epstein-Barr virus and CMV DNA as the sequence to search the sample DNA, the sequence of the cloning vehicle, the bacteriophage $\mathrm{m} 13$ as the second universal sequence. The first hybridization step with unlabeled recombinant phage DNA binds via the specific sequences and also $\mathrm{m} 13$ sequences to the filter membranc. Because single-stranded phage DNA is used, only one strand is represented and allows the use of high concentration of

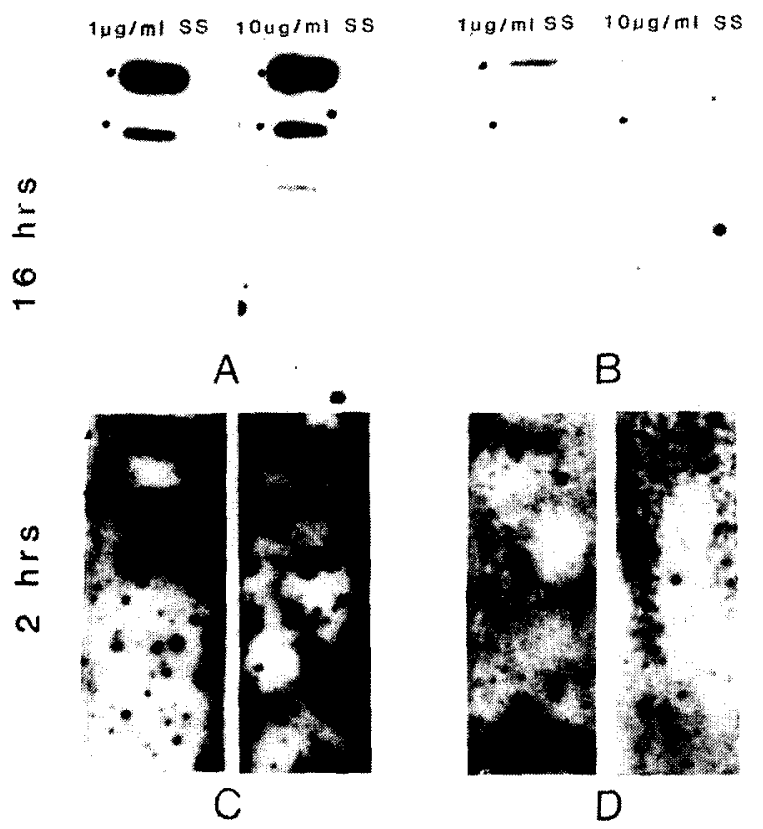

Fig. 1. (A) Two-step sand wich hybridization: $1 \mu \mathrm{g}$ and $10 \mu \mathrm{g}$ single-stranded EBWS9 m13 DNA, respective ly, were hybridized for $16 \mathrm{~h}$ at $68^{\circ} \mathrm{C}$. After washing a second hybridization followed with ${ }^{32} \mathrm{P}$ nick-translater m13 mp 8 DNA $\left(0.8 \times 10^{\prime} \mathrm{cpm}\right)$ for $16 \mathrm{~h}$ at $68^{\circ} \mathrm{C}$. (B) One-step sandwich hybridization: $1 \mu \mathrm{g}$ and $10 \mu$ single-stranded EBWS $9 \mathrm{ml} 3$ DNA clone, respectively, plus ${ }^{32} \mathrm{P}$ nick-translated $\mathrm{m} 13 \mathrm{mp} 8\left(0.8 \times 10^{7} \mathrm{cpm}\right.$ were hybridized for $16 \mathrm{~h}$ at $68^{\circ} \mathrm{C}$. (C) Two-step sandwich hybridization with concentration step: $1 \mu \mathrm{g}$ and 1 $\mu \mathrm{g}$ single-stranded EBWS9 m 13 DNA clone, respectively, were hybridized for $2 \mathrm{~h}$ at $68^{\circ} \mathrm{C}$, then allowed $\mathrm{t}$ dry at $68^{\circ} \mathrm{C}$. As a second step ${ }^{32} \mathrm{P}$ nick-translated $\mathrm{m} 13 \mathrm{mp} 8 \mathrm{DNA}\left(0.8 \times 10^{7} \mathrm{cpm}\right)$ was hybridized for $16 \mathrm{~h}$ a $68^{\circ} \mathrm{C}$. (D) One-step sandwich hybridization with concentration step: $1 \mu \mathrm{g}$ and $10 \mu \mathrm{g}$ single-stranded EBWS $\mathrm{m} 13$ DNA clone, respectively, plus ${ }^{32} \mathrm{P}$ nick-translated $\mathrm{m} 13 \mathrm{mp} 8\left(0.8 \times 10^{7} \mathrm{cpm}\right)$ were hybridized $2 \mathrm{~h}$ at $68^{\circ} \mathrm{r}$ and then allowed to dry at $68^{\circ} \mathrm{C}$. 
reusable probe DNA and short-time periods of hybridization. After removal of the excess of phage DNA, the remaining sequences of $\mathrm{m} 13$ bound via their insert can be detected in a second hybridization directed only against the $\mathrm{m} 13$ sequences. The replicative form of wild-type $\mathrm{m} 13$ (without viral insert) is a convenient source for the second-step hybridization probe. It can be labeled chemically or in any of the conventional protocols using enzymes to introduce antigenic epitopes such as biotin or isotopes.

Sandwich hybridization could be carried out as a single-step (Fig. 1, Band D) or as a double-step reaction (Fig. 1, Bands A and C). Figure 1 compares the relative sensitivities of these variations. The low sensitivity of the single-step protocol is likely due to a loss of probe from the hybridization cocktail by hybridization to the excess of unlabeled single-stranded DNA remaining unbound due to the limited amount of sample DNA.

The speed of hybridization largely depends on the concentration of nucleic acids. In order to obtain short hybridization times the filters can be incubated in open dishes to allow evaporation of solvent to near dryness. Although the background increases

$52 \quad 0.5 \quad 0.2 \quad 0.1 \quad 0.05 \quad 0.020 .01$

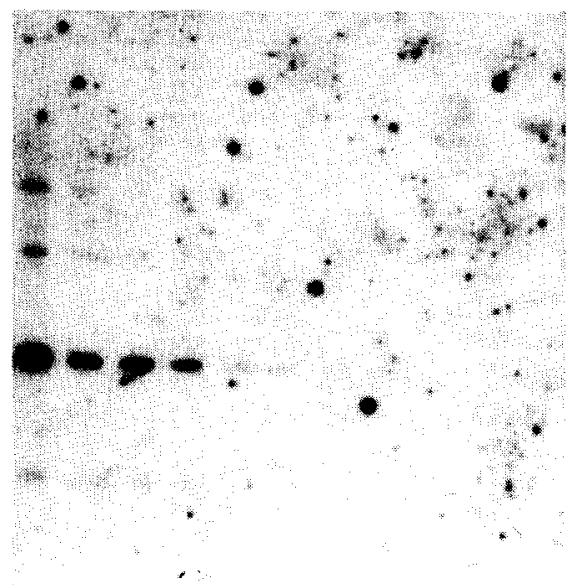

A $\begin{array}{lllllllll}5 & 2 & 0.6 & 0.2 & 0.1 & 0.05 & 0.02 & 0.01\end{array}$

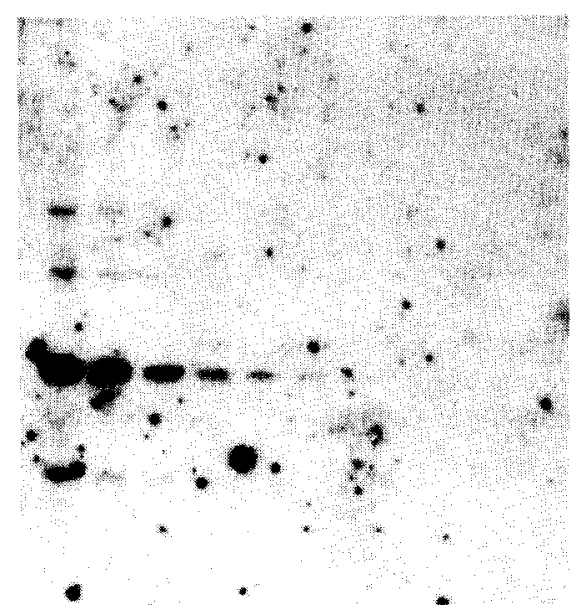

$\mathrm{B}$

Fig. 2. Influence of the length of hybridization probes to sandwich hybridization. Variable amounts of Raji cell (50 EBV genomes per cell) DNA giving in the top line of the figure in $\mu \mathrm{g}$ was digested with Bam H1 restriction enzyme, separated on an agarose gel and blotted to a nitrocellulose membrane. 1-9: Per slot 5, 2, $1,0.5,0.2,0.1,0.05,0.02,0.01 \mu \mathrm{g}$ Raji cell DNA, digested with Bam H1 were electrophoretically separated on a $1 \%$ agarose gel, and blotted to nitrocellulose paper. First step of hybridization: $1 \mu \mathrm{g}$ single-stranded $\mathrm{m} 13 \mathrm{DNA}$ (unlabeled) was hybridized for $16 \mathrm{~h}$ at $68^{\circ} \mathrm{C}$. For the second step of hybridization $10^{7} \mathrm{cpm}$ of unligated ${ }^{32} \mathrm{P}$ nick-translated RF of $\mathrm{m} 13 \mathrm{mp} 8 \mathrm{DNA}$ (panel A) or $10^{7} \mathrm{cpm}$ of ligase-treated $(0.5 \mu \mathrm{g} \mathrm{RF}$, ethanol precipitated after nick translation, dissolved in $8 \mu \mathrm{l}$ bidest, incubated with $1.5 \mathrm{U}$ ligase for $17 \mathrm{~h} \mathrm{at} 17^{\circ} \mathrm{C}$ and an additional $1 \mathrm{U}$ ligase for 3 additional $\mathrm{h}$ ) ${ }^{32} \mathrm{P}$ nick-translated $\mathrm{RF}$ of $\mathrm{m} 13 \mathrm{mp} 8 \mathrm{DNA}$ were used (panel $\mathrm{B}$ ). 
considerably, an accelerated procedure with acceptable sensitivity can be used (Fig. 1, Bands $C$ and D). Network formation should be favored by offering as a second probe DNA prepared from double-stranded DNA with longer fragments of DNA. Figure 2 shows a comparison of nick-translated RF of $\mathrm{m} 13$ without (panel A) and with ligase treatment after stopping the nick translation. Although the bands in the ligase-treated samples are clearer, there was no significant difference in the endpoint of detection of sample DNA.

Due to easy scaling up of non-enzymatic labeling procedures such as chemical iodination (Commerford, 1971; Prensky, 1976; Gu et al., 1983; Han and Harding, 1983) which functions best with single-stranded nucleic acids, it may be advantageous in some cases to use single-stranded DNA as a labeled probe. This can be combined with the advantages of universally usable probes if a three-layer sandwich can be produced. The results of a three-step sandwich hybridization is shown in Fig. 3.

A two-step sandwich hybridization with clinical material for diagnostic purposes is shown in Fig. 4. After hybridization with ${ }^{125}$ I labeled m13 CMV (Fig. 4, Bands a and c) and appropriate after four half lives of ${ }^{125} I$ expired, the same blots were used to control the method by adding second hybridization with ${ }^{32} \mathrm{P}$ labeled $\mathrm{m} 13 \mathrm{mp} 8$ (Fig. 4, Bands $\mathrm{b}$ and d).

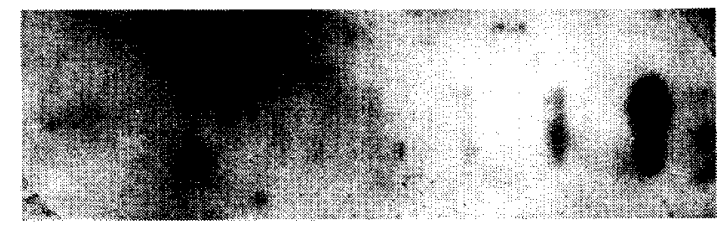

Fig. 3. Three-step sandwich hybridization. The steps were as follows: (First) $10 \mu \mathrm{g}$ single-stranded EBWS9 DNA were hybridized for $2 \mathrm{~h}$ at $68^{\circ} \mathrm{C}$, dried at $68^{\circ} \mathrm{C}$. (Second) $10 \mu \mathrm{g}$ double-stranded $\mathrm{m} 13 \mathrm{mp} 8$ were hybridized for $2 \mathrm{~h}$ at $68^{\circ} \mathrm{C}$, dried at $68^{\circ} \mathrm{C}$. (Third) $10^{7} \mathrm{cpm}{ }^{125} \mathrm{I} \mathrm{m13}$ single-stranded DNA for $16 \mathrm{~h}$ at $63^{\circ} \mathrm{C}$.

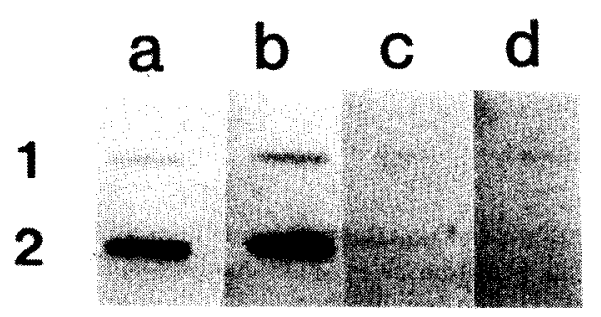

Fig. 4. Detection of CMV in urine. Samples were collected from two different patients, one positive $(a, b)$ and one negative (c,d). Slot no. 1 represents the low speed pellets and slot no. 2 the high speed pellets. (a) and (c): One step hybridization with ${ }^{12 s}$ I labeled single-stranded m13 CMV DNA; exposure time 72 h. (b) and (d): The second hybridization with ${ }^{32} \mathrm{P}$ labeled double-stranded $\mathrm{m} 13 \mathrm{mp} 8$ DNA after the first signal had been reduced by allowing 4 half-lives for decay (remaining ${ }^{125}$ I activity of $1 / 16$ of a)); exposure time $23 \mathrm{~h}$. 


\section{DISCUSSION}

Simplified hybridization procedures are necessary if the potential of this technique is to be exploited on a wider scale for clinical use. Viruses which cannot be cultivated in vitro, e.g. rotavirus and hepatitis B, or where cultivation takes too long, e.g. cytomegalovirus, dengue, hepatitis $A$ and particularly where viruses linked to proliferative diseases of man, like EBV, papillomaviruses or HTLV, require reliable and rapid tests for the presence of the respective genomic material. The increasing variety of probes raises prohibitory stock-holding problems for routine laboratories if short-lived isotope labels are used with a variety of probes. Chemical iodination of recombinant $\mathrm{m} 13$ DNA is very rapid and simple for preparing hybridization probes (Fig. 5A). Sandwich hybridization (Fig. 5B), particularly if non-radioactive sccond probes are used, is only slightly more complex but it reduces logistic problems considerably while allowing high sensitivity.

The use of sandwich hybridization for clinical specimens is particularly appropriate, and the sensitivity is comparable to one step hybridization (see Fig. 4).

Another method introduced previously, which also involves the formation of a sandwich (Virtanen et al., 1983), used a quite different approach. In contrast to the method described here, extracted DNA from clinical material, which is usually in limited supply, is used as probe in the first hybridization reaction which is determined by the concentration of the probe. In the second step, specifically labeled probes are used. Thus this method requires larger, often unavailable, amounts of clinical material and specific probes for each hybridization procedure.

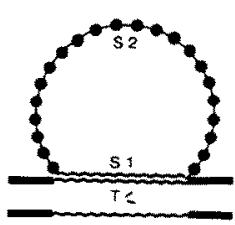

A

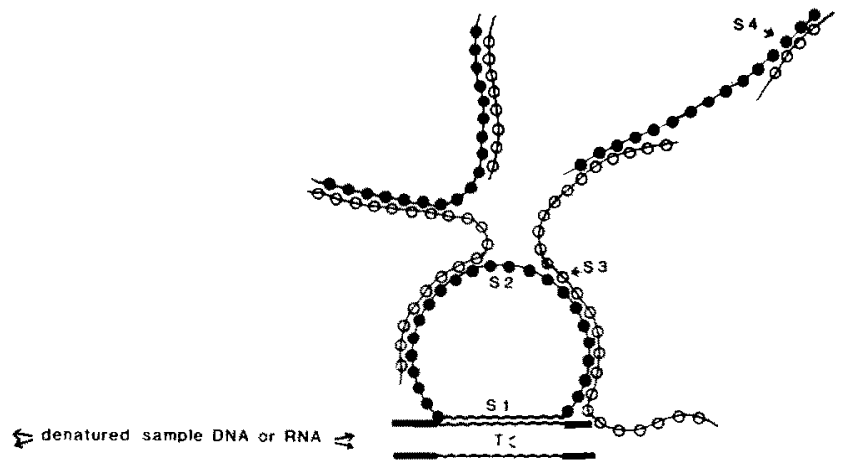

B

Fig. 5. (A) Schematic drawing of the hybridization reactions: a direct hybridization using m13 DNA (sequence S2) carrying an insert (sequence S1). The recombinant phage DNA can be labeled directly with isotopes or other markers. (B) Sandwich hybridization utilizes sequence $S 1$ as specific probe and sequence $\mathrm{S} 2$ as signal which is detected by a set of complementary sequences $\mathrm{S} 3$ and $\mathrm{S4}$, such as denatured RF of $\mathrm{m} 13$ mp8 (see Figs. 1 and 2). Additional labeled sequence 4 may be added if no labeled $R F$ is available (Fig. 3). 
Our technique takes advantage of the recombinant DNA technique and links the specific sequence 1 to another sequence 2 . Sequence 2 can conveniently be m 13 DNA. These probes are used in a first hybridization step unlabeled and in high concentrations, which favors rapid and complete hybridization in under $1 \mathrm{~h}$. After removal of excess probe, a second probe is added which is homologous to sequence 2 and ideally contains both orientations of the DNA strands. This second probe can be universally applied and under specific conditions forms a network on top of sequence 2 . An example is given in Fig. 2 where, with appropriate exposure time, as little as $200 \mathrm{fg}$ of the specific sequences represented in the probe were found in the test DNA. Attempts to increase further sensitivity by higher concentration of the probes through evaporation of solvent (Fig. 1, C, D) were not successful and produced a rather unacceptable high background. The sandwich hybridization yielded an amplification of the hybridization signal in first preliminary experiments of up to 100 -fold when nonradioactive 'second probes' were utilized. Besides using a single labeled probe for various hybridizations, the protocol concentrates the usually limiting amount of sample nucleic acid in the filter which permits optimal sensitivity in the probe driven hybridization reaction.

\section{ACKNOWLEDGEMENTS}

This work was initiated as a consequence of discussions and experience in sponsored training courses by Hans Wolf. Part of this work was supported by the Sander Foundation. The authors wish to thank Dr. Graf, Tutzing, for helpful discussions.

\section{REFERENCES}

Bresser, J., J. Doering and D. Gillespie, 1983, DNA 2, 243.

Commerford, S., 1971, Biochemistry 10, 1993.

Frenkel, N., H. Locker, B. Cox, B. Roizman and F. Rapp, 1976, J. Virol. 18, 885.

Gu, S., H. Wolf and Z. Yi, 1983, Cancer (China), 129.

I Ian, J. and J. I Iarding, 1983, Nucleic Acids Res. 11, 14.

$\mathrm{Hu}, \mathrm{N}$. and J. Messing, 1980, Gene 17, 271.

Maniatis, T., E.F. Fritsch and J. Sambroock, 1982, in: Molecular Cloning - A Laboratory Manual (Cold

Spring Harbor Laboratory, New York).

Messing, J., 1983, Methods Enzymol. 101, 20.

Peden, K., P. Mounts and G. Hayward, 1982, Cell 31, 71.

Prensky, W., 1976, Methods Cell Biol. 13, 121.

Richter, W., S. Gu, R. Seibl and H. Wolf, 1983, in: Nasopharyngeal Carcinoma: Current Concepts, eds. U.

Prasad, D.V. Ablashi, P.H. Levine and G.R. Pearson (University of Malaya Press, Kuala Lumpur).

Virtanen, M., M. Laaksonen, H. Söderlund, A. Palva, P. Halonen and M. Ranki, 1983, Lancet i, 381. 